\title{
A Preferable Approach for the Ninth Circuit
}

\author{
Procter Hug, Jr. $\dagger$ \\ Carl Tobias $\ddagger$
}

United States Senators Orrin Hatch (R-Utah) and Frank Murkowski (R-Alaska) recently introduced Senate Bill 2184, which would split the United States Court of Appeals for the Ninth Circuit into two circuits. ${ }^{1}$ This measure differs from Senate Bill 253 that embodies the recommendations submitted to Congress by the Commission on Structural Alternatives for the Federal Courts of Appeals after its one-year study. The Commission found "no persuasive evidence that the Ninth Circuit . . . is not working effectively" and clearly rejected bifurcation. ${ }^{3}$ However, the Commission recommended that Congress impose a divisional restructuring on the Ninth Circuit Court of Appeals and authorize the other appellate courts to adopt divisional arrangements when their caseloads increase. ${ }^{4}$ Because Congress is still considering both legislative proposals, they require careful assessment. This analysis reveals that the two bills do not adequately treat the concerns that animated the study; the bills actually contradict the Commission's goals ${ }^{5}$ and suggest drastic solutions for

Copyright $\odot 2000$ California Law Review, Inc. California Law Review, Incorporated (CLR) is a California nonprofit corporation. CLR and the authors are solely responsible for the content of their publications.

$\dagger \quad$ Chief Judge, United States Court of Appeals for the Ninth Circuit.

$\ddagger \quad$ Professor of Law, William S. Boyd School of Law, University of Nevada, Las Vegas. I thank Chris Bryant, Jay Bybee, Michael Higdon and Peggy Sanner for valuable suggestions, Jim Rogers for generous, continuing support, and Angela Dufva for processing this piece. We thank Mark Mendenhall, Assistant Circuit Executive, for invaluable assistance. These are our views, but they reflect those of two-thirds of the Ninth Circuit's nembers

1. See S. 2184, 106th Cong. (2000); see also 146 Cong. Rec. S1233 (daily ed. Mar. 7, 2000). Senator Hatch is the chair of the Judiciary Committee.

2. See generally Commission ON StRuctural Alternatives for the Federal Courts of APPEALS, FINAL REPORT (1998) [hereinafter COMMISSION REPORT]; see also id. at 93-99 (providing the “proposed statutes" on which senators premised S. 253).

3. COMMISSION REPORT, supra note 2, at 29.

4. See id. at 29-30.

5. For these views of circuit-splitting as well as a description of the Commission's goals, see $i d$. at ix-x, 34-37, 44, 47-50. For critical views of the divisional structure, see Federal Courts-Proposed Changes to the Ninth Circuit and the Federal Courts of Appeals, 113 HARv. L. REv. 822, 825 (2000) [hereinafter Critique]. 
problems that do not exist. Moreover, the Ninth Circuit has instituted an approach that is preferable to either alternative. A Ninth Circuit Evaluation Committee is assessing the court in light of the Commission's investigation and is crafting responses to certain concerns. Since the endeavor will be more effective than the radical, irrevocable strategies of bifurcation or divisional restructuring, the Committee's work also merits analysis. This essay undertakes that effort.

We first summarize and critically evaluate the Commission's report and recommendations. Our essay then describes and scrutinizes the reasons proffered for splitting the circuit generally and for Senate Bill 2184 in particular. Finally, we consider a less dramatic and disruptive, and more promising, means to address certain perceived concerns identified by the Commission and the sponsors of Senate Bill 2184. We conclude that the Evaluation Committee approach will better attain the objectives of the Commission and of Senate Bill 2184 proponents; therefore, Congress should reject both the divisional concept and circuit splitting.

I

\section{The Work Of The Commission And Its Recommendations}

\section{A. The Commission's Authorization and Work}

The history of the Commission has received relatively extensive treatment elsewhere. ${ }^{6}$ Congress approved the Commission principally as a response to ongoing controversy over the Ninth Circuit. ${ }^{7}$ The court's size has prompted perennial calls for reconfiguration. ${ }^{8}$ Since 1983 , lawmakers who championed a split have instituted numerous efforts to bifurcate the circuit. ${ }^{9}$ In 1997 , Congress authorized an assessment. ${ }^{10}$ The Commission had a year to study the "structure and alignment of the Federal Court of Appeals system, with particular reference to the Ninth Circuit," and to write a report with recommendations for such structural or boundary

6. See, e.g., Procter Hug, Jr., The Commission on Structural Alternatives for the Federal Courts of Appeals' Final Report: An Analysis of the Commission's Recommendations for the Ninth Circuit, 32 U.C. DAvis L. REv. 887 (1999); Jennifer E. Spreng, Three Divisions in One Circuit?: A Critique of the Recommendations From the Commission on Structural Alternatives for the Federal Courts of Appeals, 35 IDAHo L. REv. 553 (1999); Carl Tobias, Suggestions for Studying the Federal Appellate System, 49 FLA. L. REV. 189 (1997).

7. See Commission RePort, supra note 2, at 33-34. See generally Arthur D. Hellman, The Unkindest Cut: The White Commission Proposal to Restructure the Ninth Circuit, 73 S. CAL. L. REv. 377 (2000); S. REP. No. 104-197 (1995).

8. See, e.g., S. 431, 105th Cong. (1997); S. 956, 104th Cong. (1995). See generally Critique, supra note 5.

9. See Commission Report, supra note 2, at 33-34. See generally Jennifer E. Spreng, The Icebox Cometh: A Former Clerk's View of the Proposed Ninth Circuit Split, 73 WasH. L. REv. 875, 876 (1998).

10. See Departments of Commerce, Justice, and State, the Judiciary, and Related Agencies Appropriations Act of 1998, Pub. L. No. 105-119, § 305, 111 Stat. 2440, 2491-93 (1997). See generally Hellman, supra note 7, at 378-81; Hug, supra note 6, at 892-93; Spreng, supra note 6, at 560. 
changes "as may be appropriate for the expeditious and effective disposition of the caseload of the Federal Courts of Appeals, consistent with fundamental concepts of fairness and due process."11

The Commission appeared to implement carefully its important responsibilities. ${ }^{12}$ In 1998, the Commission sought written input and held six public hearings. ${ }^{13}$ It also assembled statistical data, such as the percentages of oral arguments and published opinions that the court affords, the time needed for resolving appeals, and the measures employed since the 1970s to address caseload increases. ${ }^{14}$ In October, the Commission issued a tentative draft report with recommendations and solicited public comment on this tentative draft for thirty days. ${ }^{15}$ After considering the public input, the Commission issued a minimally-changed final report that suggested that Congress require a divisional approach for the Ninth Circuit Court of Appeals and empower the other courts to apply divisional concepts as they grow. ${ }^{16}$

In January 1999, Senators Slade Gorton (R-Wash.) and Murkowski introduced Senate Bill 253, proposed legislation that essentially einbodies the Commission's suggestions. ${ }^{17}$

11. Pub. L. No. 105-119, § 305(a)(1)(B)(ii)-(iii), 111 Stat. at 2491. See generally Tobias, supra note 6 , at 206-11.

12. We rely in this paragraph on Commission Report, supra note 2, at 1-6 and Carl Tobias, $A$ Federal Appellate System for the Twenty-First Century, 74 WASH. L. Rev. 275, 295-98 (1999).

13. See Commission RePorT, supra note 2, at 2-3; see also Joseph N. Akrotirianakis et al., JerryBuilding the Road to the Future: An Evaluation of the White Commission Report on Structural Alternatives for the Federal Courts of Appeals, 36 SAN DIEGo L. REv. 355, 362 (1999).

14. See Commission Report, supra note 2, at 21-25, 39; see also Report of THE Federal COURTS STUDY COMMITTEE 109 (1990) (stating that caseload increases have transformed the circuits).

15. See Commission on Structural alternatives for the Federal Courts of Appeals, Tentative Draft Report (Oct. 1998). See generally Hug, supra note 6, at 893-94; Spreng, supra note 9 , at $877-78$.

16. See Commission Reporr, supra note 2, at iii, 40-47, 59-76. See generally Hug, supra note 6, at 897-98; Spreng, supra note 6, at 577-86; Tobias, supra note 12, at 304-10.

17. Compare S. 253, 106th Cong. (1999) with COMMISSION REPoRT, supra note 2, at 93-99; see also supra note 4 and accompanying text. In July of 1999, the Senate and House each held a committee hearing on the proposed legislation and on the final report prepared by the Commission. See Review of the Report by the Commission on Structural Altematives for the Federal Courts of Appeals Regarding the Ninth Circuit and S. 253, the Ninth Circuit Reorganization Act: Hearing Before the Senate Judiciary Subcomm. on Admin. Oversight and the Courts (1999) [hereinafter Senate Hearing]; Oversight Hearing on the Final Report of the Commission on Structural Alternatives for the Federal Courts of Appeals Before the House Judiciary Subcomm. on Courts and Intellectual Property (1999) [hereinafter House Hearing]. Between the dates of the Senate and House hearings, Senator Dianne Feinstein (D-Cal.) introduced a bill that would essentially reform the en banc process. See S. 1403, 106th Cong. (1999); 145 Cong. Rec. S8884 (daily ed. July 20, 1999); see also infra notes 93-94, 102 and accompanying text. 


\section{B. Analysis of the Commission Report and Recommendations}

The Commission analyzed the circuit's pressures, emphasizing size, ${ }^{18}$ and canvassed ideas favoring and opposing bifurcation. Advocates of a split contended that circuit case law lacks sufficient consistency; that the court cannot decide appeals in a timely fashion; that its judges are unable to "keep up with the large volume" of opinions; and that there is inadequate judicial collegiality and interpersonal communication. ${ }^{19}$ Moreover, the limited en banc process is purportedly flawed because it does not represent the unified voice of the circuit membership and contributes to a high Supreme Court reversal rate. ${ }^{20}$

Those arguing against bifurcation pointed out that over two-thirds of Ninth Circuit judges oppose a split and believe the limited en banc process works well. ${ }^{21}$ The court is among the fastest circuits in resolving cases once argued or submitted to panels, and any delay in processing appeals from the time of filing is attributable to excessive vacant judgeships. ${ }^{22}$ Opponents also contended that the court has established a sophisticated issuetracking system that allows judges to stay informed of the current law, that the judges are as collegial as those in any circuit, and that technology's continued use will improve communication and case disposition. ${ }^{23}$

Although the Commission possessed no empirical data to justify a major change in Ninth Circuit structure, it proposed restructuring the court of appeals into three semi-autonomous divisions. Each division would review its panel decisions en banc, and a Circuit Division would consider only "square interdivisional conflicts."24 The Conmission stated that its plan to modify the structure of the Ninth Circuit would enhance predictability, communication, and ties to local communities, yet retain a large circuit's admmistrative benefits. ${ }^{25}$

18. These include geographic scope, 28 active appellate judgeships and 8,700 annual appeals. See COMmISSION REPORT, supra note 2, at 30-32; Critique, supra note 5, at 823.

19. Commission RePORT, supra note 2, at 34-35, 38-40; see also Critique, supra note 5, at 823.

20. See COMMISSION REPORT, supra note 2, at 34-37; Critique, supra note 5, at 823; see also Act of Oct. 20, 1978, Pub. L. No. 95-486, § 6, 92 Stat. 1629, 1633 (1978) (authorizing the limited en banc process); 9TH CIR. R. 35-3 (implementing the limited en banc process).

21. See Commission RePORT, supra note 2, at 35-36, 38; Critique, supra note 5, at 824; Hug, supra note 6, at 897-98, 906-08.

22. See COMmission REPORT, supra note 2, at 34. Judicial vacancies complicate efforts to assemble sufficient argument panels. See id; see also Commission ON Structural Alternatives FOR THE FEDERAL COURTS OF APPEALS, WORKING PAPERS 95, tbl.7 (1998) (affording relevant data on disposition times) [hereinafter WORKING PAPERS].

23. See COMMISSION REPORT, supra note 2, at 34-36; Critique, supra note 5, at 823-24; see also infra note 100 and accompanying text.

24. COMmission REPORT, supra note 2, at 40-45. The Commission specifically rejected circuitsplitting as an acceptable solution for docket growth. Id. at 44; see also infra notes $64-70$ and accompanying text.

25. See COMMission REPORT, supra note 2, at 47-50; see also Critique, supra note 5, at 824 . 
The most troubling feature of the divisional arrangement is the Commission's determination to abandon circuit-wide stare decisis. ${ }^{26}$ The divisional concept would jettison the existing circuit-wide en banc court and encourage inconsistent circuit law by permitting the judges in one division to ignore the precedent of the other two divisions. ${ }^{27}$ Moreover, the Circuit Division, the Commission's major remedy for this situation, would be unresponsive principally because of its narrowly circumscribed authority ${ }^{28}$ For instance, under Senate Bill 253, the Circuit Division could treat only direct conflicts between divisions and could not entertain cases sua sponte. ${ }^{29}$ The Commission's approach would also eliminate current informal procedures that enable any judge to notify panel members of possible departures from circuit precedent and to maintain consistency absent en banc hearings. ${ }^{30}$

Implementation of the divisional plan would lead to additional complications. First, applying this idea would impose a new layer of judicial review. ${ }^{31}$ Indeed, the chief judges of seven appellate courts trenchantly admonished that the "whole concept of intracircuit divisions, replete with its two levels of en banc review, has far more drawbacks than benefits." ${ }^{32}$ Second, the Supreme Court may be reluctant to hear cases from a single division that contradict opinions issued by a circuit; even were the Justices amenable to review, there would be greater pressure on the Supreme Court to resist the balkanization of federal law. ${ }^{33}$ Third, the Circuit Division's thirteen members would rotate slowly and, thus, could "lock out strong dissenting voices." ${ }^{34}$ The present eleven-judge limited en banc court, consisting of the chief judge and ten judges drawn at random, is much more representative of the full court than the proposed Circuit Division's thirteen members - the chief judge and twelve judges, four from each division for

26. See Hellman, supra note 7, at 382-83; Hug, supra note 6, at 909.

27. See Akrotirianakis et al., supra note 13, at 380-81; Hellman, supra note 7, at 384, 390; Hug, supra note 6 , at 909 .

28. See Hellman, supra note 7, at 384-88; see also Tobias, supra note 12, at 306-07.

29. See S. 253, 106th Cong. (1999); Commission Report, supra note 2, at 45; Hug, supra note 6, at $909-10$.

30. See Hellman, supra note 7, at 390; Hug, supra note 6, at 907. For more discussion of Circuit Division authority, as well as how its decisions' limited impact and the divisions' operation essentially as separate courts would make law of the circuit nearly irrelevant, see Hellman, supra note 7, at 384$88,390-91$.

31. See Critique, supra note 5, at 825; House Hearing, supra note 17 (statement of Ronald Olson).

32. Harry T. Edwards et al., Memorandum from Chief Judge to the Commission on Structural Alternatives for the Federal Courts of Appeals (Nov. 10, 1998) $<$ http://app.comm.uscourts.gov/report/comments/Becker.htm> ; accord Hug, supra note 6, at 899-906, 909-15.

33. See Critique, supra note 5, at 825 . The Supreme Court alone would resolve conflicts between a division and a circuit. See CoMmission REPoRT, supra note 2, at 45.

34. Critique, supra note 5, at 825-26. 
three-year terms-would be..$^{35}$ Moreover, the full court would no longer participate in the en banc process by calling for en banc reconsideration or voting on whether to take a case en banc under the arrangeinent that the Commission recommended. ${ }^{36}$ The Commission's approach would also effectively divide the court "into three circuits" with little justification for their boundaries or added costs. ${ }^{37}$

Notwithstanding these criticisms, the plan might warrant consideration if the Commission had identified a serious failing that smaller decisionmaking entities could rectify. However, no empirical data demonstrate the existence of any such problems. The Commission's rationale for the divisional arrangement was that the "law-declaring function of appellate courts requires groups of judges smaller than the present Ninth Circuit Court of Appeals." 38 The Commission concomitantly premised this conclusion on two intertwined notions: (1) "the inability of judges [on large circuits] to monitor all the decisions the entire court of appeals renders"39 and (2) "large appellate units have difficulty developing and nuaintaining consistent and coherent law."40

These propositions cannot withstand scrutiny. The idea that inembers of a court nust read, remember, and catalog every opinion to keep up with and apply circuit law is "a relic of the pre-computer era."41 The Commission confused quite different actions: staying abreast of circuit precedent and monitoring of panel decisions. ${ }^{42}$ The Commission expressed concern about the "volume of opinions produced by the Ninth Circuit" but neglected to state that quantity does not correspond with circuit size, a phenomenon manifested by three other circuits having issued more

35. See Hug, supra note 6 , at 907 . Compare sources cited supra note 20 with Commission REPORT, supra note 2 , at 45 . Because the Northern Division would have only $22 \%$ of the caseload and, thus, presumably $22 \%$ of the judges, and the Southern Division would have $47 \%$ of the caseload and $47 \%$ of the judges, Circuit Division representation would not proportionately represent the full court. See CoMmission REPORT, supra note 2, at 45; see also Hug, supra note 6, at 909, 915.

36. Compare sources cited supra note 20 and infra note 91 with CoMMIssion REPORT, supra note 2 , at 45 .

37. Critique, supra note 5, at 826-27; see also CoMmission REPORT, supra note 2, at ix-x, 36; Hellman, supra note 7, at 392-93 (claiming that the plan would divide the Court of Appeals). The idea in the text is especially troubling, as the Commission lauds a unified circuit's interpretation of federal law in the West and preservation of large-scale administrative efficiency. See Critique, supra note 5, at 826-27; infra note 48 and accompanying text.

38. COMMISSION REPORT, supra note 2 , at 47.

39. Id.

40. Id.

41. Procter Hug, Jr., Letter from Chief Judge Procter Hug, Jr., Ninth Circuit Court of Appeals to Justice Byron R. White, United States Supreme Court (Aug. 29, 1998) <http://app.comm.uscourts.gov/hearings/submitted/hug.htm>.

42. See Hellman, supra note 7, at 394-95.

43. COMMISSION REPORT, supra note 2 , at 47. 
published decisions than the Ninth Circuit in $1998 .^{44}$ Professor Arthur Hellman finds "the evidence leaves no doubt that the judges of the Ninth Circuit Court of Appeals engage in a substantial amount of opinion monitoring." ${ }^{25}$ His empirical research shows, and the experience of former Ninth Circuit Judge J. Clifford Wallace confirms, ${ }^{46}$ the weakness in the Commission assertion that large appellate entities cannot maintain consistent and coherent law. In short, no convincing empirical data support the drastic modification that the Commission advocated. ${ }^{47}$

Without fairly evaluating how well the Ninth Circuit operates today, the Commission implied that size alone presents a conundrum that justifies radical change. The Commission actually conceded that large size affords benefits. For example, the Commission hailed a unified court's ability to construe federal law and realize operational efficiencies. ${ }^{48}$ Pamela Rymer-a Ninth Circuit judge and a commissioner who strongly advocates the Commission plan-similarly testified: "no one seriously questions how the circuit performs its administrative functions. The circuit's size allows for flexibility in assignment [and] economies of scale."'49

In short, the Commission's recommendation for a divisional restructuring would neither address the concerns that prompted the study nor realize the Commission's own specifically-articulated objectives. ${ }^{50}$ Splitting the Ninth Circuit would also fail to treat the concerns or attain the goals, as the next section demonstrates.

44. See Administrative OfFice of U.S. Courts, Judicial Business of the UNIted States Courrs 1998 54, tbl.S-3 (1999).

45. Hellman, supra note 7, at 395; see also id. at 395-96 (adducing evidence from procedure whereby off-panel judges can use the en banc process to raise questions about opinions); supra note 30 and accoinpanying text (discussing that procedure).

46. See Hellman, supra note 7, at 397-401; infra notes $79-80$ and accompanying text (citing his work); J. Clifford Wallace, The Case for Large Federal Courts of Appeals, 77 JUDICATURE 299 (1994).

47. The absence of examples and few specifics are symptomatic of limited evidentiary support, while the Commission's allusions to "perceptions" of greater inconsistency in the Ninth Circuit and to its own "judgment, based on experience" are weak foundations for such radical change. Commission REPORT, supra note 2, at 47; see also Hellman, supra note 7, at 397-401; Tobias, supra note 12, at 31112.

48. See Commission RePort, supra note 2, at ix-x, 36; Critique, supra note 5, at 827 n.46.

49. Senate Hearing, supra note 17; accord Hellman, supra note 7, at 401-02; Critique, supra note 5 , at 827 n.51.

50. These goals include relieving the Supreme Court without balkanizing federal law, increasing the legitimacy of the limited en banc process, and retaining a large circuit's major benefits. See COMMISSION REPORT, supra note 2, at 36,48-50; Critique, supra note 5, at 822-25. For more discussion of these, and other, criticisms, see Hug, supra note 6, at 909-15; Critique, supra, at 824-27; Hellman, supra note 7 , at $381-401$. 
II

\section{The Proposals To Split The Ninth Circuit}

\section{A. Rationales for Circuit-Splitting}

Some of the criticisms of the divisional structure may have led to the March 2000 proposal of legislation that would split the Ninth Circuit. ${ }^{51}$ Senate Bill 2184 was only the latest of numerous attempts to reconfigure the circuit. Since 1983, there have been five major efforts; the most recent had commenced in 1995 and culminated in the compromise that authorized the Commission. . $^{2}$

Circuit-splitting proponents have presented numerous overlapping rationales for bifurcation, many of which the Commission reproduced and we discussed above..$^{53}$ Advocates of circuit-splitting also argue that California perspectives, judges, and appeals dominate the court. ${ }^{54}$ The Commission alluded to this contention, ${ }^{55}$ even as it declared that " $[t]$ here is one principle that we regard as undebatable: $1 \mathrm{t}$ is wrong to realign circuits ... and to restructure courts . . . because of particular decisions or particular judges." 56 Over time, champions of bifurcation have variously phrased these propositions and accorded them different emphases. Current proponents downplay the role of California and politics, ${ }^{57}$ while they emphasize the concerns regarding court administration and other Commission rationales.

\section{B. Analysis of Senate Bill 2184}

Senate Bill 2184, introduced in March 2000 by Senators Hatch and Murkowski, ${ }^{58}$ would establish a new Twelfth Circuit consisting of Alaska, Guam, Hawaii, Idaho, Montana, the Northern Mariana Islands, Oregon,

51. See supra note 1 and accompanying text.

52. See Thomas E. Baker, On Redrawing Circuit Boundaries-Why the Proposal to Divide the United States Court of Appeals for the Ninth Circuit is Not Such a Good Idea, 22 ARız. ST. L.J. 917, 928-34 (1990); Hellman, supra note 7, at 379-80; Tobias, supra note 6, at 198-214.

53. These reasons include size, inadequate collegiality and interpersonal communication, slow case resolution and insufficiently consistent and coherent circuit law that allegedly results from the inability of judges to "keep up with the large volume" of opinions and of the court to perform its ent banc functions effectively. CoMmission REPORT, supra note 2, at 34-37; see also supra notes 19-20 and accompanying text.

54. See Baker, supra note 52, at 940-43; Carl Tobias, The Impoverished Idea of Circuit-Splitting, 44 EMORY L.J. 1357, 1371-73 (1995). A recent incarnation of this argument appears in a Senate debate over confirmation. "[T]he 9th Circuit has become lopsided with activist judges that has helped push it far out of the judicial mainstream .... Confirming Richard Paez and Marsha Berzon to the 9th Circuit would only exacerbate its problems." 146 CoNG. REC. S1298 (daily ed. Mar. 8, 2000) (statement of Sen. Bunning).

55. See COMMISSION REPORT, supra note 2, at 36.

56. Id. at 6 . "This rule must be faithfully honored, for the independence of the judiciary is of constitutional dimension and requires no less." $1 d$.

57. See supra notes 53-54 and accompanying text.

58. See 146 CoNG. REC. $S 1233$ (daily ed. Mar. 7, 2000). 
and Washington, leaving Arizona, California, and Nevada in the Ninth Circuit. ${ }^{59}$ The sponsors supported the proposal with previously-enunciated reasons, such as intra-circuit inconsistency, a high reversal rate, inability of the courts' nienibers to monitor all opinions, and deficiencies in the limited en banc process. ${ }^{60}$ Senator Hatch explained the last two ideas:
Absent the ability of each active judge on the Ninth Circuit to read each ... published decision, there can be no assurance that calls will be made for en banc review of those cases which judges believe merit rehearing, ... . [while the en banc] systen is being utilized with insufficient frequency . . . [and] a limited en banc decision ... [may] not reflect the views of a majority of the circuit's judges. ${ }^{61}$

Senator Murkowski specifically stated that Senate Bill 2184 was a "more direct and simplified solution to the problems of the Ninth Circuit" than the divisional arrangement with which a few Senate members "were not too happy." $" 62$

Among the many reasons that Congress should not enact Senate Bill 2184 , there are some ideas that resemble the criticisms of the divisional approach as well as others that include the Commission's cogent arguments against bifurcation. ${ }^{63}$ The Commission saw "no good reason to split the circuit solely out of concern for its size or administration ... . [or] the consistency, predictability, and coherence of circuit law," while "splitting the circuit would impose substantial costs of administrative disruption [and] the monetary costs of creating a new circuit." considered bifurcation an improper long-term solution to the caseload increases that most appellate courts will encounter. ${ }^{65}$ For example, circuitsplitting could further burden the Supreme Court and additionally splinter federal law, mainly by increasing intercircuit inconsistency. ${ }^{66}$ The Commission also observed that this remedy would "deprive the West and

59. See S. 2184, 106th Cong. (2000).

60. Each ascribed these to size. See 146 CoNG. REc. at S1233-34 (statement of Sen. Murkowski); id. at S1234-35 (statement of Sen. Hatch); see also supra notes 19-20, 53 and accompanying text.

61. 146 CoNG. REC. at S1235. He stated that two circuits, whose judges "will have one-half as many of their colleagues' opinions to read," would better promote error correction and coherence. $I d$.

62. Id. at $\mathrm{S} 1233$.

63. In light of our analysis above, certain arguments deserve relatively limited treatment here. However, additional consideration is warranted because the Commission is an authoritative source that carefully analyzed the issues. Moreover, it was unable to respond directly to the sponsors' contentions.

64. Commission RePort, supra note 2 , at ix, 29. The Commission expressly stated that bifurcation would sacrifice administrative advantages, including flexible judicial assignments and specific economies of scale. See supra notes $48-49$ and accompanying text.

65. See COMMISSION REPORT, supra note 2, at $\mathrm{x}$, 44; see also WORKING PAPERs, supra note 22, at 93, tbl.1 (affording caseload data).

66. See, e.g., Thomas E. Baker \& Douglas D. McFarland, The Need for a New National Court, 100 Harv. L. REv. 1400, 1404-09 (1987); Tobias, supra note 54, at 1386-87; Critique, supra note 5, at 824. 
the Pacific seaboard of a means for maintaining uniform federal law in that area." ${ }^{367}$ Praising the administrative advantages of retaining a unified circuit, the Commission confidently concluded that the divisional concept would vitiate the need for a split. ${ }^{68}$ The Commission explored more than a dozen possibilities for bifurcation and "found no merit in any:" 69

[I] $t$ is impossible to create from the current Ninth Circuit two or more circuits that would result in both an equitable number of appeals per judge and courts of appeals small enough to operate with the sort of collegiality we envision, unless the State of California were to be split between judicial circuits-an option we believe to be undesirable. ${ }^{70}$

The Commission and other observers correctly concluded that the complex geographic and demographic configuration of the Ninth Circuit makes it defy bifurcation. ${ }^{71}$ The recent bill, like numerous earlier measures, would require judges of the proposed Ninth Circuit to address a considerably larger, more complicated docket than judges of the projected Twelfth Circuit. ${ }^{72}$ A split would correspondingly eliminate the appellate court that has long employed, and experimented with, creative measures to address mounting appeals. ${ }^{73}$ The circuit should continue this ambitious testing because caseload growth and comparatively limited resources suggest that most courts will increasingly resemble the Ninth Circuit, which will serve as a model..$^{74}$

67. COMMISSION REPORT, supra note 2, at $\mathrm{x}$. It similarly declared that having one court in the West interpret federal law, especially "commercial and maritime laws that govern relations with [other Pacific Rim nations is a strength] that should be maintained." Id. at 49-50.

68. See id. at 52; see also supra notes $48-49$ and accompanying text.

69. COMMISSION REPORT, supra note 2, at 53; see also infra notes 71-74 and accompanying text.

70. COMmISSION REPORT, supra note 2, at 52.

71. See supra notes $69-70$ and accompanying text; see also Baker, supra note 52 , at $938,945-46$; Tobias, supra note 54, at 1409-15.

72. See, e.g., S. 431, 105th Cong. (1997); S. 956, 104th Cong. (1995); Carl Tobias, Why Congress Should Not Split the Ninth Circuit, 50 SMU L. REv. 583, 590-91 (1997). These ideas contradict Senator Hatch's claim that each new court's judges would read only half as many cases. See supra note 61.

73. See Joe Cecil, Fed. Judicial Ctr., Administration of Justice in a Large Appellate Court: The Ninth Circuit Innovations Project (1985); Restructuring Justice: The InNovations of the Ninth CIRCuIt AND THE Future of THE FEDERAL Courts (Arthur D. Hellman ed., 1990). The Commission seemed to recognize this by finding Ninth Circuit administration "on a par with that of other circuits, and innovative in many respects," creativity that screening panels' use illustrates. COMMISSION REPORT, supra note 2, at ix; see also infra notes 106-107 and accompanying text (analyzing screening panels).

74. See, e.g. , Hellman, supra note 7, at 402; Wallace, supra note 46. Responses to the sponsors' ideas elsewhere obviate the need for more treatment here. For example, insofar as they repeat the Commission ideas about large courts and the reversal rate, we have addressed the ideas. Compare supra notes 19-20, 38-40, 60 and accompanying text with supra notes $41-47$, infra notes $96-98$ and accompanying text. For a thorough critique of circuit-splitting, see ThOMAs E. BAKER, RATIONING Justice on Appeal: The Problems of the U.S. Courts of APPEALS 99-105 (1994). 
In sum, the major difficulty with both the divisional concept and circuit-splitting is misplaced reliance on unsupported assumptions that the Ninth Circuit experiences severe problems and, therefore, should be restructured into divisions or into two separate courts to resolve the complications. ${ }^{75}$ No empirical data demonstrate that the Ninth Circuit has serious failings or requires such dramatic alteration. ${ }^{76}$ Finally, drastic change should be rejected when more promising measures are readily available.

\section{III}

\section{The NinTh CIRCUIT APPROACH}

In contrast to the proposed draconian solutions of restructuring into autonomous divisions or circuit-splitting, the Ninth Circuit has adopted a tempered approach for addressing the perceived shortcomings reported to or considered by the Commission. In 1999, shortly after the Commission issued its final report, the Ninth Circuit Court of Appeals established an Evaluation Committee. The Committee has assessed and continues to analyze circuit processes and procedures and has already suggested a score of ways to enhance operations in areas highlighted by the Commission. ${ }^{77}$

\section{A. Consistent and Certain Circuit Law}

Both the Commission and the sponsors of Senate Bill 2184 erroneously assert that Ninth Circuit law lacks uniformity and coherence. ${ }^{78}$ The "only systematic study" of the operation of precedent in a large court, which assessed efforts "to maintain a consistent body of law," "the pattern of [multiple relevant precedents] exemplified by high visibility issues . . . is not characteristic of Ninth Circuit jurisprudence generally. Nor is intracircuit conflict." $\$ 0$ The Commission acknowledged, yet

75. Neither the great majority of judges and lawyers in the Ninth Circuit nor those appearing at the hearings in the Ninth Circuit or submitting statements think so. See Hug, supra note 6, at 897.

76. Change so drastic as the Commission and the sponsors urge in a century-old institution should occur only if empirical data clearly show that the court experiences serious difficulties. See Judicial Conference of the U.S., Long Range Plan for the Federal Courts 44-45 (1995).

77. See Ninth Circuit Evaluation Committee, Interim Report (2000) [hereinafter Evaluation COMmittee, InTERIM Report]. In July 1999, the Committee solicited the bar's input on the en banc process, consistency and certainty, regional concerns and calendaring, delay and productivity, written and oral advocacy, mediation and technology. See id. at 1-2.

78. See supra notes 19,60-61 and accompanying text.

79. Judith McKenna, Fed. Judicial CTr., Structural and OTher Alternatives for the Federal Courts of ApPeals 94 (1993). The Federal Judicial Center is the courts' research arm. See 28 U.S.C. $\$ 620$ et seq. (1994).

80. Arthur D. Hellman, Maintaining Consistency in the Law of the Large Circuit, in RESTRUCTURING JUSTICE, supra note 73 , at 86 . The study covered two distinct years of Ninth Circuit opinions, which the court decided over a much longer period. See McKenNA, supra note 79, at 94; Hellman, supra note 7 , at 398 . 
essentially ignored, that study ${ }^{81}$ and did not even mention a subsequent Federal Judicial Center evaluation that mirrors the initial study's findings. ${ }^{82}$ Admitting that the Commission lacked time to conduct a "statistically meaningful analysis" of all Ninth Circuit dispositions to make an objective determination, ${ }^{83}$ the Commission undertook a survey of the court's district judges and lawyers that provided only inconclusive results ${ }^{84}$ and ultimately conceded that "consistency and predictability [defy] statistical analysis." 85

In short, neither the Commission nor the circuit-splitting advocates presented empirical data to document that the court's law is less uniform than that of the remaining circuits. All of the empirical data actually suggest otherwise. Nevertheless, because the Evaluation Committee thought that circuit size could lead to a perception of inconsistency, it focused on strengthening the capacity of the court for early detection and immediate treatment of possible or apparent conflicts. ${ }^{86}$ The Committee asked that judges and counsel notify the court of inconsistencies among unpublished memorandum dispositions and between those decisions and published opinions, creating an "electronic mailbox" to facilitate this exchange. ${ }^{87}$ Moreover, it urged, and the Advisory Rules Committee has implemented, a two-year experiment whereby lawyers may cite unpublished memorandum dispositions in petitions for rehearing or requests for publication in order to identify perceived conflicts. ${ }^{88}$ The circuit is also currently testing the Committee's proposed system in which staff attorneys employ their

81. See COMmission REPORT, supra note 2, at 39 n.93. "It is the Commission's prerogative to reject the methods or conclusions of empirical research, but it is regrettable that the Commission simply gives up and declares that the concepts are too subtle to warrant analysis." Hellman, supra note 7 , at 398.

82. "[D]espite concerns about the proliferation of precedent as the courts of appeals grow, thcre is currently little evidence that intracircuit inconsisteney is a significant problem . . . [or] that whatever intracircuit conflict exists is strongly correlated with circuit size." McKENNA, supra note 79, at 94; accord Hellman, supra note 7, at 398.

83. COMMISSION REPORT, supra note 2, at 39.

84. For example, district judges "find[] the law insufficiently clear to give them eonfidence in their decisions on questions of law about as often as their counterparts in other circuits," while attorneys report "somewhat more difficulty discerning circuit law and predicting outcomes of appeals than lawyers elsewhere." Id. at 39-40; see also Hellman, stupra note 7, at 399 (urging "caution in interpreting the survey results").

85. COMMISSION REPORT, supra note 2, at 40. "These eoneepts are too subtle, the decline in quality too incremental, and the effects of size too difficult to isolate, to allow evaluation in a frcezeframed moment." Id. But see supra note 81.

86. See Evaluation Comimitee, INTERIM RePort, supra note 77, at 8-10.

87. See Chief Judge Procter Hug, Jr., Responding to Ninth Circuit Concerns: The Innovative Work of the Evaluation Committee 2 (2000) (unpublished manuscript, on file with author); Memorandum from Office of the Clerk, U.S. Court of Appeals for the Ninth Circuit, to Members of the Academic Community (Jan. 2000) (on file with author) (providing the conflicts form).

88. See Evaluation Committee, Interim RePORT, supra note 77, at 6-7. Lawyers can also alert the circuit to conflicts. See Hug, supra note 87, at 2; see also 9TH C1R. R. 36-3 (Circuit Rule 36-3 has been adopted for a limited 30-month period, beginning July 1, 2000 and ending December 31, 2002. Thereafter the Advisory Committee on Rules will issue a recommendation on whether the rule should be made permanent). 
subject-matter expertise and objective criteria to monitor rehearing en banc petitions to identify potential inconsistencies and sensitive decisions for careful judicial scrutiny. ${ }^{89}$

\section{B. The Limited En Banc Process}

The senators who introduced Senate Bill 2184 seemingly accepted without question the Commission's claims that the en banc process is not representative and prompts the Supreme Court to reverse many cases. ${ }^{90}$ Both notions are unpersuasive. The circuit believes the limited en banc process uses scarce institutional resources effectively and respects all judges' interest in law-declaration. ${ }^{91}$ However, to address the perception of unrepresentativeness, the Evaluation Committee commissioned an expert, independent study that reaffirmed the legitimacy of the process by finding that eleven members do "fairly represent the court as a whole." Despite this conclusion, the Committee asked the circuit to examine enlarging the en banc court and reducing the number of votes needed to take a case $e n$ banc, potentially expanding the quantity of annual appeals heard en banc. ${ }^{93}$ The court endorsed these concepts as a "reasoned, responsible alternative to the radical restructuring proposed by Senate Bill 253 " because it is "as concerned with perceptions as with reality."94 In recognition that the changes will increase en banc reconsideration, the circuit has also begun to experiment with quarterly sessions of the en banc court. ${ }^{95}$

The proposition that the limited en banc device contributes to a high reversal rate in the Supreme Court is even less convincing. The reversal rate has minimal relevance to court administration and structure. Circuit Judge Rymer, a Commission member, "representing and speaking on its behalf," testified that the reversal rate "is not a problem that the Commission identified or . . . believes should weigh into the consideration

89. The criteria include invalidation of a statute or issuance of a dissent. See Hug, supra note 87, at 2. The Committee is evaluatiug internal review of all cases for consistency before their release. See id.

90. Compare supra notes 60-61 and accompanying text with supra note 20 and accompanying text.

91. See Hug, supra note 87 , at 3 . Each active and senior judge can request en banc rehearing, while the entire process promotes productive exchange regarding legal issues. See id.

92. Id. at 3-4. An en banc court of eleven judges is approximately $94 \%$ representative statistically. Since Congress authorized the limited en banc court in 1978, the court bas issued over 170 decisions. A third of the opinions were unanimous, and $75 \%$ had a majority of eight to three or greater, which strongly suggests that a full-court en banc would have reached identical decisions. Id. at 3 .

93. See Evaluation Committee, Interim Report, supra note 77, at 2-6. Senate Bill 1403, 106th Cong. (1999), which Senator Dianne Feinstein introduced, embodies these ideas and regional assignments, discussed infra notes 94, 102 and accompanying text; see also supra note 17.

94. Hug, supra note 87 , at 4 . The circuit also endorsed regional assignments. See id. at 2; see also infra note 102 and accompanying text.

95. See Evaluation Committee, InTERIM Report, supra note 77, at 5-6. 
of structural alternatives. ${ }^{396}$ Moreover, the ten-year reversal rate statistics reveal that the number of Ninth Circuit decisions overturned has never exceeded one half of one percent of the total circuit terminations on the merits. ${ }^{97}$ The Ninth Circuit's reversal rate was also lower than the median reversal rate for three years and within eight percentage points of the median for two, and it was highest of all the circuits in only one year out of the ten. ${ }^{98}$

\section{Collegiality and Communications}

The sponsors of Senate Bill 2184 appeared to adopt uncritically the Commission's claims that the circuit lacks collegiality and interpersonal communication. ${ }^{99}$ However, these notions defy empirical verification, as the Commission frankly admitted in stating that collegiality "cannot be quantified or measured," even as it recognized that continuing reliance on technology will improve communication and case resolution. ${ }^{100}$ The Evaluation Committee found no problems with collegiality in the Ninth Circuit; however, the Committee has proffered several ideas on regionalism and calendaring to address perceived concerns about communications, collegiality, circuit linkages with the areas served, and the need for regional viewpoints in appellate decisionmaking. ${ }^{101}$ It proposed, and the circuit is testing, regional assignments that require one judge from the administrative unit out of which the appeal arises to serve on the panel hearing the case. ${ }^{102}$ Moreover, the Committee recommended, and the court has employed, oral argument sittings in more cities and combined them with bench-bar activities to improve communications throughout the circuit. $^{103}$

6.

96. Senate Hearing, supra note 17. For similar ideas, see CoMmISSION REPORT, stpra note 2, at

97. See Ninth Circuit Court of Appeals Law Library Table on U.S. Supreme Court REVERSAL RATES (1998).

98. See id; see also Jerome Farris, The Ninth Circuit-Most Maligned Circuit in the CountryFact or Fiction?, 58 OHю ST. L.J. 1465 (1997); Marybeth Herald, Reversed, Vacated, and Split: The Supreme Court, the Ninth Circuit, and the Congress, 77 OR. L. Rev. 405 (1998). Another concern is circuit inability to keep up with the volume of cases.See supra notes 19, 39, 43 and accompanying text. But see supra notes $41-42,44-47$ and accompanying text.

99. Compare Hatch and Murkowski Statements, supra note 60 with supra note 19 and accompanying text.

100. Commission Report, supra note 2, at 40; see also Critique, supra note 5, at 824. For analyses of collegiality, see FranK CofFIN, ON APPEAL: CoURTS, LAWYERING, AND JUDGING 215 (1994); Harry T. Edwards, Collegiality and Decision Making on the D.C. Circuit, 84 VA. L. REv. 1335, 1358-62 (1998); Deanell Reece Taeha, The "C" Word: On Collegiality, 56 OHo ST. L.J. 585 (1995).

101. See Evaluation Committee, InTerim Report, supra note 77, at 12-13.

102. See id.

103. See id. at 13. In 1999 alone, the court held oral arguments and bench-bar meetings in Anchorage, Coeur d' Alene (Idaho), Missoula (Mont.), San Diego, Phoenix, and Honolulu. See id. 


\section{Productivity and Expediting Review}

In response to perceived concerns about case delays, the Evaluation Committee has instituted several actions to enhance productivity and expedite review. ${ }^{104}$ It has suggested, and the court is experimenting with, increased "batching" of cases that involve similar issues or statutes before the same argument panel for faster disposition. ${ }^{105}$ The Committee has urged continuing use of the innovative oral motions and screening calendars ${ }^{106}$ in which a panel considers relatively uncomplicated appeals-ones that clear precedent readily resolves-in deciding 340 motions and 140 cases each month. ${ }^{107}$

For the reasons stated, we believe that the faulty assumptions and premises, as well as the lack of empirical data, that underlie the Commission's work and the recent sponsorship of Senate Bill 2184 raise serious questions about the wisdom of implementing the changes that the Commission and circuit-splitting advocates champion. Nevertheless, the Evaluation Committee has begun to treat perceived concerns, and the court has already implemented many of the Committee's recommendations. Fortunately, the circuit can apply most of the proposals without congressional authorization. These measured, well-considered steps to address perceived concerns, if coupled with prompt Senate confirmation of nominees for the current circuit vacancies, ${ }^{108}$ should enable the court to function at the peak of its abilities and eliminate any concerns about circuit operations. The Committee's approach will relieve the Supreme Court, yet not splinter federal law, by limiting intracircuit and intercircuit inconsistency; will enhance the validity of the en banc process, primarily through increased frequency of application; and will retain a large circuit's benefits because it would leave the circuit intact. In sum, the Evaluation Committee approach should attain the goals of the Commission and the sponsors of Senate Bill 2184 with greater efficacy and less disruption than their proposals.

\section{ConClusion}

The Commission on Structural Alternatives for the Federal Courts of Appeals and the introduction of Senate Bill 2184 have advanced the

104. See supra note 19 and accompanying text.

105. See EVAluation COMMITteE, InTERIM RePORT, supra note 77, at 71 .

106. See Hug, supra note 87.

107. See id.; Commission RePort, supra note 2, at 31 . The above measures and other actions show that the circuit is treating concerns apart from ones voiced by the Commission and the sponsors, and is responsive to all of its consumers. The process is ongoing, and the court is committed to continuing self-analysis and to more testing and innovation which will foster even greater future efficacy. See Hug, supra note 87.

108. See supra note 22 and accompanying text. See generally Carl Tobias, Filling the Federal Appellate Openings on the Ninth Circuit, 19 Rev. LITIG. 233 (2000); sources cited supra note 54. 
dialogue about the Ninth Circuit. However, the court's continued application of, and experimentation with, a broad spectrum of promising measures will better address the concerns identified than either the divisional concept or circuit-splitting. Congress is now considering the two more drastic approaches, but it should reject them as ineffective and unduly disruptive. 